\title{
Analysis and Domestic Case Study of Venture Capital
}

\author{
An'na Li \\ School of Economics, Jinan University, Guangzhou, China \\ Email: annalee_jnu@163.com
}

How to cite this paper: Li, A.N. (2017) Analysis and Domestic Case Study of Venture Capital. American Journal of Industrial and Business Management, 7, 464-472. https://doi.org/10.4236/ajibm.2017.74033

Received: March 6, 2017

Accepted: April 23, 2017

Published: April 26, 2017

Copyright (C) 2017 by author and Scientific Research Publishing Inc. This work is licensed under the Creative Commons Attribution International License (CC BY 4.0).

http://creativecommons.org/licenses/by/4.0/

\begin{abstract}
This paper introduces the definition of venture capital and its development characteristics in China at present, then analyzes its promoting functions on domestic high-tech enterprise. From the perspective of both theoretical and practical, we analyze about government's influence upon venture capital, and discuss the ways in which the government fully plays its role guiding the development of VC. According to the discussion above, effective policy suggestions are given at the end of this paper.
\end{abstract}

\section{Keywords}

Venture Capital, Guiding Fund, New and High Technology Industries, Government Guidance

\section{Definition and Characteristics of Venture Capital}

\subsection{Definition of VC}

Venture capital (VC) is an established economic concept with a specific meaning. In general, VC refers to all kinds of investment with high risk and high potential returns. Specifically, VC can be defined as investment that bases on hightech and in production and management of technology-intensive products in narrow sense. The latter commonly invests in the early stages of development of high-tech start-ups [1]. Rising from the Silicon Valley in the United States to the global trend of establishing high-tech industry development zones and science and technology industrial parks, VC plays an increasingly important role in high-tech industry development and an invaluable role in boosting a nation's technological development.

\subsection{Characteristics of VC}

Among all channels of investments, VC shows distinct differences with other 
forms of investment.

First of all, it can be characterized as high-expected return and high risk. VC is a kind of high risk investment behavior while its high risk is associated with the investment. High-tech enterprises innovation of high-tech enterprises is based on the results of scientific research and the application of new technologies. Only after going through a series of complicated steps such as technology research, product development can a new scientific and technological result turn into a new product. Each link is at risk of failing, which means, it may encounter lots of uncertainties. However, higher risks bring greater returns so the concept of "high risk high gain" promotes the rapid development of VC.

Secondly, VC is long-term equity capital. VC can be categorized as risky and long-term investment, thus also known as "brave and patient capital" [2]. VC needs to be initiated during a venture business's early stage while it will take a long time for the investors to receive gains. VC is a kind of equity capital by not only looking for dividend income or interest income but also final capital gains. It aims at assisting the venture business to add value to its asset development instead of focusing on current profits.

Thirdly, this kind of investment will usually consider high-tech firms and companies with greater growth potentials. VC is the core driving force of the development of high-tech industry. For example, US VC concentrates on developing computer software, bio-technology, Internet and health care. Nevertheless, VC not only invests in high-tech enterprises, it is looking for high-growth projects that can bring larger returns on investments.

Lastly, VC possesses a management model of indirect intervention and an optimistic motivation system. Since venture business starts receiving VC, the company's governance structure shows the separation of ownership and management. Venture capitalists share a stake in venture enterprises while the firm will be given the right of operation and management. To safeguard their rights and interest, venture capitalists will pay close attention to the corporate management condition. Normally, they will not interfere too much with the company's daily business, but via offering a series of advice to influence and assist the enterprise to achieve better operation and efficient management. Meanwhile, VC may relieve the problem of incentive system, especially if the corporate form is private VC or limited partnership with overseas capital. With the ratio of contribution to the fund around $2 \%$ and up to $20 \%$ of the profits, the management team is undoubtedly highly encouraged in better performance.

\section{Literature Review}

Since first introduced to China in 1980s, VC has been continually attracting attentions not only in practical investment but also in theoretical research. Especially after it was listed as Proposal No.1 by Chinese people's political consultative conference in 1998, the topic of VC appealed to plenty of scholars and encouraged great research achievement, which prompted the rapid and steady development of VC in China. 


\subsection{Summary of Experience of Western Countries in VC}

Yulin Zhao and Yuwen Zhou [3] published a paper named "US experience in venture capital and China's development in science and technology VC". In the thesis, the researchers had a penetrating insight into the US's rich experience in $\mathrm{VC}$ and expounded the needed systematically supporting environment. Based on the empirical study, several suggestions and recommendations on domestic development of VC were claimed, aiming to make an early exploration in the adaptation of VC in China.

Xinli Zhang [4] made an in-depth exploration into the relationship between VC and the economic growth of the US. The empirical result suggested that there is a long-run and dynamic relationship between these two factors. Hopefully this result can draw effective enlightenment to the domestic VC development and boost the economic growth at the same time.

Yiguo Xu [5] from the Chinese academy of social sciences financial research institute examined the general situation of the development of VC industry after the financial crisis in the US, and carried out a particular investigation, in order to provide reference for the US government in policy formulation.

Yamin Wang and Ronglin Zhu [6] made a brief review on the European VC development history and analyzed systematically with SCP framework of modern industrial organization theory. They found out that investment behavior in Europe is largely determined by the traits of low market concentration and high withdraw barrier. This indicates that VC in Europe mainly flows to the latter stages of non tech enterprises.

\subsection{Research on the Support of VC to New and High Technology Industries}

Guoqing Lu [7] considered that it still remains at the first level of function while the investors provide capitals for research and development of the start-up companies. However, there are three significant aspects of function that can not be neglected. Firstly, VC accelerates the transformation of scientific research achievements and the industrialization of high and new technology "incubator". Secondly, VC cultivates outstanding entrepreneurs that not only master in management but also can handle technological problems. Thirdly, VC works as the thruster of financial innovation. Via a more developed VC market, the finance industry especially the investment banking sector can get greater progress.

Yiming Yuan [8] regarded that VC came into being as a result of the insufficient support that new and high technology industries received from traditional finance industry. As a main kind of innovational financial capital, the fundamental motive of venture investment lies in the appreciation of venture capital.

\section{The Role of VC in the Economic Development}

On the whole, VC mainly promotes economic development from three aspects.

Firstly, VC is mainly invested in start-up small and medium-sized enterprises.

To a certain extent, it eases the financing difficulties of small and medium-sized 
enterprises. In the present, financing channel of small and medium-sized enterprises lacks of diversification, mainly by bank loans. But the procedure of loans is complicated and time consuming, while the enterprises are in urgent demand of money. Besides, with the problem of credit insufficiency, they can't get enough credits to satisfy the huge funding gap. And the private lending market is in irregular management. VC can solve part of the financing difficulties of small and medium-sized enterprises.

Secondly, VC primarily invests in high-tech enterprise, which helps to upgrade China's industrial structure. Energy-intensive and high pollution industries dominate in the present economy in China. But it's not traditional industry but high-tech enterprises that VC enters. High-tech enterprises can often bring higher profits, and moreover their development can make a better change to the current economic situation.

Thirdly, VC can promote the standardization of the enterprise development while introducing more efficiency and energy to the enterprise, since VC usually represents the advanced management technology and the organizational superiority. As VC intervenes in the enterprise management procedure, the enterprise can greatly benefit from taking advantage of more efficient management technology, optimizing the organizational structure, reducing the internal cost, and as a result, promote its competitiveness in the long term.

\section{The Role of Government in the Development of VC in China}

There is no doubt that the Chinese government plays an important role in the development of VC.

The direct intervention of the government contributed to the rise of VC. In the early 1980s, the national science and technology commission and British experts studied on how to develop high-tech industry in China. British experts strongly recommend the development of VC. In 1985, the establishment of the ever first VC institution was realized under the government's direct promotion.

Government intervention promoted the development of VC. After the first appearance of VC, all levels of government introduced various policies and measurements to promote the development of $\mathrm{VC}$, involving the investment and financing mechanism, financial policy, tax policy, expanding the channels of funding sources, etc. VC is a high-risk high-yield way of innovational investment. In addition to the market size and growth prospects of the investment industry, good internal and external environment is essential to the development of VC. In the process of the development of VC in China, government plays an indispensable role.

\section{A Case Analysis in Government VC Guiding Fund [9]}

\subsection{Taking Suzhou City as an Example to Explore the Development Mode of VC Fund}

Suzhou Industrial Park VC Guiding Fund was originally set up by Suzhou VC 
Group and National Development Bank, with a scale of RMB 1 billion for a period of 13 years. The operation of the Guiding Fund is under corporate system. Profit of the funs is distributed on an average basis between Suzhou VC Group and the National Development Bank. Suzhou Park Ginkgo Investment Management Co., Ltd. was entrusted as the fund manager. Its sub-fund has been invested in various fields, with the investment ratio less than $30 \%$, the registered capital higher than 100 million yuan and need to get registered in the park. The main features of its operational model are as follows:

1) Guide the establishment of investment decision-making committee. It is for the committee to be responsible for the prior due diligence of VC enterprise. The investment share plan is also issued, and afterwards, verified and qualified by the committee.

2) A sub-fund basically consists of a fund and a management company. The duration is generally between 7 and 8 years, up to 10 years at most.

3) In choosing partners, a long-term industry experience is of most importance. The team's overall team capacity, historical performance, and investment strategy are also taken into consideration.

4) The fund needs to be operated according to the market, and the distribution of the profits must follow the principle that "the shares of the same class shall have the same rights and benefits". The trustees will not participate in the daily operation of the management team and, but the sub-fund is required to give the quarterly and annual investment report.

\subsection{The Results of VC Guiding Fund of Suzhou City}

Remarkable results have been achieved since the operation of the guiding fund of Suzhou Industrial Park, which includes:

First, the capital leverage amplification effect is obvious. Suzhou Industrial Park VC Guiding Fund has set up 16 sub-funds by 2010, with a total scale of 4.3 billion yuan, of which there are 8 sub-funds with foreign cooperation background. The government invested 1 billion yuan, leveraging 33 Billion yuan of social funds. The capital leverage turns out to be around 3.3.

Second, it has provided evident support to a large number of enterprises of high-tech industry. The Suzhou Industrial Park has successfully invested in nine sub-funds and developed more than $40 \mathrm{VC}$ projects. As the equity investment participated, some related enterprises have the chance to get support in finance, market and technology, which promotes the development and growth of these enterprises. Among them, the typical cases include the JiangSu Shengquan Fund, which was established by Suzhou Industrial Park Guiding Fund. It invested RMB 4 million to Focus Technology Company to solve its financing difficulties, which played a vital role in the development of the company. The company gained rapid growth after the investment, becoming the third largest B2B business in China, after Ali and Global Resources.

Finally, it has promoted the high-speed growth of local VC industry. The establishment of the Guiding Fund shows the determination of Suzhou govern- 
ment in developing the local VC industry. As the policy's guidance function begins to perform, some well-known VC enterprises, from domestic or overseas, have gradually come to Suzhou, in search of cooperation. So far, there has been more than 20 equity investment management team settled in Suzhou Industrial Park Shahu equity investment center, managing more than 30 funds, achieving a total size of 30 billion yuan, supporting more than 270 enterprises.

\section{Remaining Problems in China's VC Industry}

\subsection{A Narrow Source of Funding and Insufficient Investment}

At present, China's VC mainly comes from overseas investment, listed companies, government funding, science and technology enterprises and private enterprises. China's development model, being government-led, results in uneven investment structure, the lack of competition, non-standard operation, inefficiency offinancing channels, which led directly to the small size of VC and the inefficiency of investment.

\subsection{Lack of Capital Structure Diversity}

At present, China's VC mainly comes from fiscal appropriation and bank science and technology development loans. As the national financial resources is limited, the proportion of funds in the financial expenditure is gradually decreasing. Banks, on the other hand, under the requirement of risk prevention, are controlling the scale of science and technology development loans. Consequently limits the size of VC funds, but also results in the ineffectiveness in risk diversification.

\subsection{Lack of Effective Channels for VC to Withdrawal}

The vitality of VC lies in the circulation of funds. The core mechanism is the withdraw mechanism [10]. This requires a practical smooth withdraw channel, which is also the essential difference between venture investment and industrial investment. Without convenient withdraw channels, it's impossible for VC to achieve capital appreciation and form a virtuous capital circle. As a result, venture investors won't be attracted into the field of VC.

\subsection{The Development of VC Intermediaries Is Lagging Behind}

At present, China's VC market required certain intermediary service agencies, such as industry associations, standards certification authorities and intellectual property assessment agencies, etc. The development of intermediaries is seriously lagging behind. Problems like low quality of personnel and imperfect credit system are huge barriers to the development of intermediaries.

\subsection{Imperfect Policies and Regulations}

In terms of legal protection, the legal environment of $\mathrm{VC}$ is far from perfection, especially in the areas of intellectual property, corporate system, partnership and 
so on. There are many conflictions in our existing economic laws and regulations that against the rules of $\mathrm{VC}$ operation. It requires further revision of the legal system to catch up with the development of VC.

\subsection{Extreme Lack of Professional Personnel}

At present, most of the domestic VC still remain in the academic forum and theoretical research level. Most people working in VC industry are lack of professional knowledge and relevant experience. The amount of experienced professionals equipped with practical operative abilities is in serious shortage.

\section{Policy Suggestions}

VC model of high-tech enterprise is about the way how VC is constructed and organized. It is an external form; and the study of this model effect is about the way how VC plays its role. It is an inner form. Only with the perfect combination of external and internal, can the functions of VC be fully displayed. VC started late in China. There is a big gap between the development of domestic and foreign high-tech enterprises. Although the current high-tech VC has promoted domestic GDP to some extent, but its role in corporate innovation is not fully performed. This is also indicating a great potential in the development of China's VC. Foreign high-tech enterprise VC model can be used for reference, but can not be copied. What we need is to launch a deep analysis and make appropriate adjustments to the existing model to accord with China's development path, to better promote the impact of VC.

\subsection{To Fully Play the Role of Banks, Insurance and Other Financial Institutions}

At present, VC funds come mainly from the state-owned institutions, but the government-led VC is under bad intervention and being inefficient. It's preventing the enterprises from developing independently adapting to market. It is time to gradually change the government-led pattern into a government-assisted form. At the same time, expand other sources of funding. Banks and insurance absorb funds from individuals and institutions. If these funds can be used for venture investment, it will be able to bring greater effects. Therefore, we should relax the restrictions for the bank, insurance and other financial institutions to enter venture investment. In addition, the proportion of foreign capital is insufficient. It's believed that enterprises can be greatly benefited from foreign capital considering offoreign investors' professional knowledge as well as their rich experience.

It is worth mentioning that pension fund institutions are not mentioned above, although they play an extremely important role in the United States. In the US pension mechanism is very mature, while in our country situation is different. Domestic pension mechanism has to be improved for a long time, and before it grows mature enough, investing the funds to venture industry is clearly inappropriate. 


\subsection{To Encourage the Organizational Form of General Partnership and Subsidiary Corporation}

At present, China's high-tech enterprises are mostly of company structure. Under this kind of organizational form, Venture capitalists tend to care only their profit instead of the company's performance, which leads to huge risks in the long term. However, when it comes to general partnership, venture investors can get a clearer image of their responsibilities and moreover provide necessary managerial help. So the general partnership should be highly encouraged. It's mentioned above banks and insurance participating in VC. For such investors with their own independent businesses, a subsidiary corporation system should be introduced. In this way, it is not only beneficial to the business management, but also can reduce the risks of banks and insurance company.

\subsection{To Guide VC Institutions to Get Involved in the Early Beginning Period of High-Tech Enterprises}

It's reasonable for current VC firms to invest in the mid-term stage of start-up high-tech enterprise out of risk consideration. However, this may on the other hand creates stagnation for lots of good projects. Undoubtedly, VC will face a greater risk with an early entry into the enterprise. To manage the risk, VC will be more invested into the management operations as well as technology development. This brings a fundamental upgrade to the high-tech enterprises, fulfilling the goal of VC. In addition to encouragement, it's of most necessity for VC institutions to be more skillful in the evaluation and selection of investment projects. Make use of a variety of channels to fully understand the information of all aspects of the investment projects to make a reasonable judgment. Abundant of prior investigation can reduce the risk effectively, so that institutional investors are more willing to invest in the early stage.

\subsection{To Make Full Use of the GEM (Growth Enterprise Market) for IPO}

It's suggested because after the company listed, it can be open to the community, subject to public supervision, and also open to the public financing. The establishment of the GEM undoubtedly provides a good new choice for VC to withdraw, but there have been many problems. Although the GEM listing threshold is not high, companies now listed in the GEM are mostly more mature business, coupled with intentional speculation, making the GEM "three high" phenomenon very obvious, that is, high $\mathrm{PE}$ ratio (price earning ratio), high issue price and high over raise. The role of the GEM is a financing platform for the entrepreneurial enterprises with growth potential to develop better. The companies listed on the GEM should be good start-up businesses with great potential. After the companies are listed, encourage venture investors to withdraw step by step from the enterprise rather than exit at one time. On one hand, this can implicate the good performance of venture companies, as well as development potential. On the other hand, enterprises can still receive some certain help from VC to pre- 
vent serious setbacks after listed.

\section{References}

[1] Huang, X.H. (1999) International Experience of the Development of Risk Investment and the Countermeasures of Our Country. Financial Theory and Practice, No. 5, 12-16.

[2] Zhang, F. (2009) Venture Capital for Small and Medium-Sized Enterprises Board: An Empirical Study of IPO Effect. Journal of Economics and Management Research, No. 5, 10-19.

[3] Zhao, Y.L. and Zhou, L.W. (1998) The Risk Investment Experience and the Development of Science and Technology of China Venture Capital. Journal of Wuhan University of Technology.

[4] Zhang, X.L. (2008) The Risk Investment and Economic Growth Analysis. Science and Technology and Industry, 12-16.

[5] Xu, Y.G. (2009) Recent US Venture Capital Funds Operation. China Science and Technology Investment, 35-36.

[6] Wang, Y.M. and Zhu, R.L. (2003) The Development History, Status Quo and Trend of European Venture Capital Industry. World Economy Study, No. 1, 70-75.

[7] Zhao, X.L. (2009) Research on Venture Capital and High-Tech Industry. Journal of Reform and the Strategy, 73-75.

[8] Yuan, Y.M. (2002) The Mode of the International Venture Capital Operation. Journal of Shenzhen University, 34-37.

[9] Zuo, Z.G. (2011) Effectiveness of Government Intervention in the Venture Capital: Empirical Evidence and Enlightenment. Journal of Financial Research, No. 5, 123 133.

[10] Zhong, Z.J. (2008) Try to Talk about Our Country Venture Capital Guiding Fund Legal Safeguard Mechanism, High-Tech Zone in China. No. 2, 86-87.

Submit or recommend next manuscript to SCIRP and we will provide best service for you:

Accepting pre-submission inquiries through Email, Facebook, LinkedIn, Twitter, etc. A wide selection of journals (inclusive of 9 subjects, more than 200 journals) Providing 24-hour high-quality service User-friendly online submission system Fair and swift peer-review system Efficient typesetting and proofreading procedure Display of the result of downloads and visits, as well as the number of cited articles Maximum dissemination of your research work

Submit your manuscript at: http://papersubmission.scirp.org/

Or contact ajibm@scirp.org 